\title{
PENGARUH PEMBERIAN INSENTIF TERHADAP MOTIVASI KERJA PEGAWAI PADA KANTOR LEMBAGA PENJAMINAN MUTU PENDIDIKAN (LPMP) \\ BANDAR LAMPUNG
}

\author{
The Effect of Giving Incentives on Employee Work Motivation at The Office of \\ Education Quality Assurance Institutions (LPMP) \\ Bandar Lampung
}

\author{
Aprilianto Amir ${ }^{1}$, Riswati $^{2}$ \\ Program Studi Administrasi Bisnis, FISIP, Universitas Tulang Bawang Lampung \\ aprilianto.amir@gmail.com
}

\begin{abstract}
Human resources have a very important role in an agency, for that in order for the agency to achieve goals as expected, high employee motivation is needed. Generating a high employee motivation is not easy to implement. Therefore, employees should be given appropriate incentives so that the desired employee motivation can be achieved. The provision of incentives can be done by providing annual bonuses, employee welfare, and promotions.

As for the main problem with this research is "does the provision of incentives affect the work motivation of employees at the Office of the Education Quality Assurance Institute (LPMP) Bandar Lampung?" In line with the main problem, the authors propose the hypothesis "There is a positive influence between the provision of incentives on employee motivation at the Office of the Education Quality Assurance Institution (LPMP) Bandar Lampung".

In the research that the author did, the research variable was the provision of incentives as the independent variable $(X)$ while employee motivation as the dependent variable $(Y)$. Furthermore, the proposed sample is 26 employees which is $25 \%$ of the total population, namely 105 employees. The type of research in this writing is qualitative and quantitative research with the method used is to collect data by means of surveys or field research. While the data collection techniques by means of observation, documentation, interviews and questionnaires.

Then to test the hypothesis using qualitative and quantitative analysis which is the type of this writing, with statistical formulas. Quantitative analysis using the product moment formula and obtained: rxy product moment $=0.714$. Confused with the level of evenness of the 2 variables being at a high level of closeness, it means that the incentive distribution has a very high relationship with employee performance.

To find out the effect of giving incentives on employees' work motivation, using a determinant coefficient with a result of 51\%, while other factors $49 \%$ were not examined including leadership style, office layout, atmosphere (work climate) of employees.
\end{abstract}

Keywords: incentives, work motivation, Education Quality Assurance Institute

\section{ABSTRAK}

Sumber daya manusia memiliki peranan yang sangat penting dalam suatu instansi, untuk itu agar di dalam instansi tersebut dapat mencapai tujuan seperti yang diharapkan diperlukan adanya motivasi kerja pegawai yang tinggi. Menghasilkan suatu motivasi kerja pegawai yang tinggi tidaklah mudah untuk dilaksanakan. Oleh karna itu sudah semestinya pegawai diberikan insentif yang sesuai agar motivasi kerja pegawai yang diinginkan dapat tercapai. Pemberian insentif dapat dilakukan dengan cara memberikan bonus tahunan, kesejahteraan pegawai, serta promosi.

Adapun yang menjadi masalah pokok dengan penelitian ini adalah "apakah pemberian insentif berpengaruh terhadap motivasi kerja pegawai pada Kantor Lembaga Penjaminan Mutu 
Pendidikan (LPMP) Bandar Lampung?" Sejalan dengan masalah pokok tersebut, maka penulis mengajukan hipotesis "Adanya pengaruh yang positif antara pemberian insentif terhadap motivasi kerja pegawai pada Kantor Lembaga Penjaminan Mutu Pendidikan (LPMP) Bandar Lampung". Dalam penelitian yang penulis lakukan, yang menjadi variabel penelitian adalah pemberian insentif sebagai variabel bebas $(\mathrm{X})$ sedangkan motivasi kerja pegawai sebagai variabel terikat ( Y). Selanjutnya yang diajukan sampel adalah 26 orang pegawai yang merupakan $25 \%$ dari jumlah populasi yang ada yaitu 105 orang pegawai. Tipe penelitian dalam penulisan ini adalah penelitian kualitatif dan kuantitatif dengan metode yang digunakan yaitu melakukan pengumpulan data dengan cara survey atau penelitian lapangan. Sedangkan teknik pengumpulan datanya dengan cara pengamatan, dokumentasi, wawancara dan kuisioner.

Kemudian untuk menguji hipotesis menggunakan analisis kualitatif dan kuantitatif yang merupakan tipe dari penulisan ini, dengan rumus statistik. Analisis kuantitatif menggunakan rumus product moment dan didapatkan: rxy product moment $=0,714$. Dikonsuitasikan dengan tingkat kerataan 2 variabel berada pada tingkat keeratan tinggi, berarti pemverian insentif mempunyai hubungan keeratan dengan kinerja pegawai sangat tinggi.

Untuk mengetahui besar pengaruh pemberian insentif terhadap motivasi kerja pegawai menggunakan koefisien penentu dengan hasil 51\%, sedangkan faktor lain $49 \%$ tidak diteliti diantaranya gaya kepemimpinan, tata ruang kantor, suasana (iklim kerja) pegawai.

Kata kunci: insentif, motivasi kerja, Lembaga Penjaminan Mutu Pendidikan

\section{PENDAHULUAN}

\subsection{Latar Belakang Masalah}

Hasil kerja yang telah dicapai oleh pegawai pada suatu instansi terlihat setelah pegawai itu melaksanakan pekerjaan. Hasil kerja pegawai pada suatu instansi khususnya instansi pemerintah dapat dicapai dengan maksimal apabila para pegawai pada instansi tersebut diberikan kesempatan untuk menerapkan sistem kerja yang baik. Hal ini seharusnya menjadi perhatian pimpinan atau lembaga yang berwenang guna pengembangan organisasinya, sehingga apa yang menjadi tujuan dari organisasi tersebut dapat terlaksana sesuai yang diharapkan.

Pada ruang lingkup yang kecil, suatu instansi pada saat ini ditemukan hambatan-hambatan dalam pelaksanaan tugas-tugas sebagaimana diharapkan tanpa adanya suatu penerapan sistem kerja yang baik dan terus menerus. Apabila para pegawai selalu diberikan bentuk motivasi dengan baik, kerjanya dihargai, diperhatikan, menghargai bakatnya, mengembangkan kemampuan-kemampuan yang dimiliki pegawai dan mempunyai disiplin kerja yang tinggi maka instansi tersebut pasti menjadi berkembang secara tugas pokok instansi tersebut dapat berjalan dengan baik, sebab para pegawainya bekerja secara aktif dan berusaha untuk bekerja maksimal.

Peranan sumber daya manusia sangan menentukan terhadap tercapainya tujuan dari organisasi baik pemerintah maupun swasta. Sumver daya manusia yang dapat bekerja secara efektif diperlukan dalam suatu organisasi sehingga proses penyelesaian pekerjaan dapat terlakasana tepat pada waktunya. Untuk itu, sumber daya manusia yang ada dalam suatu organisasi harus dapat dimanfaatkan dengan selalu memberikan dorongan atau semangat kerja sehingga akan terbentuk motivasi kerja. Motivasi kerja adalah suatu dorongan yang diberikan kepada pegawai agar pekerjaannya dapat meningkat dan menghasilkan prestasi.

Motivasi kerja sangat penting guna meningkatkan sumber daya manusia yang baik, terampil dan cakap dalam bidangnya sehingga tugas yang dibebankan kepadanya dapat dilaksanakan dengan efektif dan 
mempunyai disiplin kerja, tanggung jawab serta hubungan kerjasama yang baik antara sesama pegawai. Motivasi kerja tidak hadir begitu saja dalam diri pegawai, ada upaya yang harus dilakukan. Salah satu upaya yang dapat dilakukan untuk membangkitkan motivasi kerja pegawai adalah dengan memberikan perhatian kepada pegawai dalam bentuk insentif.

Pegawai merupakan bagian dari suatu organisasi yang memiliki kebutuhan biologis juga memiliki kebutuhan rohani atau bersifat psikologis. Dengan menyadari bahwa pegawai mempunyai kebutuhan dan harapan yang berbeda, pemberian insentif baik itu material insentif maupun non material insentif, dapat dilakukan sebagai salah satu bentuk pemenuhan kebutuhan pegawai yang diharapkan maupun meningkatkan motivasi kerja pegawai.

Salah satu lembaga pemerintah yang menciptakan motivasi kerja pegawai dengan memberikan insentif berupa bonus tahunan, kesejahteraan pegawai, dan promosi adalah Kantor Lembaga Penjaminan Mutu Pendidikan (LPMP). Berdasarkan Permendiknas No 7 Tahun 2007 tentang Organisasi dan Tata Kerja Lembaga Penjaminan Mutu Pendidikan (LPMP), tugas pokok LPMP adalah melaksanakan penjaminan mutu Pendidikan Dasar dan Menengah termasuk Taman Kanak-Kanak (TK), Raudatul Athfal (RA), atau bentuk lain yang sederajat di provinsi berdasarkan kebijakan Menteri Pendidikan Nasional.

Sehubungan dengan hal yang telah diuraikan, penulis menuangkannya dalam bentuk skripsi dengan judul "Pengaruh Pemberian Insentif terhadap Motivasi Kerja Pegawai Pada Kantor Lembaga Penjaminan Mutu Pendidikan (LPMP) Bandar Lampung".

\subsection{Tujuan dan Kegunaan Penelitian}

\subsubsection{Tujuan Penelitian}

1. Untuk mengetahui pemberian insentif yang diterapkan pada pegawai kantor Kantor Lembaga Penjaminan Mutu Pendidikan (LPMP).

2. Untuk mengetahui pengaruh pemberian insentif terhadap motivasi kerja pegawai pada Kantor Lembaga Penjaminan Mutu Pendidikan (LPMP).

\subsubsection{Kegunaan Penelitian}

1. Untuk membandingkan teori yang diperoleh dengan kenyataan di lapangan.

2. Diharapkan dapat memberikan masukan bagi kantor Kantor Lembaga Penjaminan Mutu Pendidikan (LPMP) khususnya mengenai pemberian insentif dan pengaruhnya terhadap motivasi kerja pegawai.

\subsection{Kerangka Pemikiran}

Mengingat banyaknya tugas-tugas yang harus dilaksanakan oleh pegawai pada Kantor Lembaga Penjaminan Mutu Pendidikan (LPMP), maka peranan pemberian insentif sangat mempengaruhi motivasi kerja pegawai dalam usaha pencapaian tujuan diperlukan sumber daya manusia yang berkualitas, sehingga tujuan yang diharapkan dapat tercapai seefektif mungkin. Dalam skripsi ini membahas pemberian insentif yang diterapkan pada suatu instansi pemerintah kepada pegawainya dengan tujuan agar para pegawai dapat termotivasi untuk bekerja lebih baik, antara lain meliputi: penghargaan, gaji, kesejahteraan pegawai, dan promosi.

"Bahwa penilaian kerja pegawai adalah suatu kerja yang dicapai seseorang dalam melaksanakan tugas-tugas yang dibebankan kepadanya yang didasarkan atas kecakapan, pengalaman dan 
kesanggupan. Prestasi ini adalah gabungan dari ketiga faktor penting yaitu kemampuan dan minat seseorang pekerja, kemampuan penerima atas tugas dan peran serta tingkat motivasi seseorang pekerja, sedangkan yang dimaksud dengan kerja adalah pengorbanan jasa-jasa jasmani dan fikiran untuk menghasilkan barangbarang atau jasa-jasa dengan

\section{Gambar 1. Paradigma Penelitian}

\begin{tabular}{|l|}
\hline \multicolumn{1}{|c|}{$\begin{array}{c}\text { Pemberian Insentif } \\
(\text { Variabel X) }\end{array}$} \\
\hline Indikator : \\
1. Bonus Tahunan \\
2. Kesejahteraan Pegawai \\
3. Promosi \\
\hline
\end{tabular}

\author{
Motivasi Kerja Pegawai \\ (Variabel Y)
}

Indikator :

1. Prestasi

2. Disiplin Kerja

3. Tanggung Jawab

\subsection{Hipotesis}

Hipotesis adalah merupakan jawaban sementara dari suatu penelitian yang harus diuji kebenarannya dalam research (Kartini Kartono, 1990:70)

Secara umum hipotesis dapat diartikan sebagai: "Dugaan yang mungkin benar atau mungkin salah, hipotesis akan ditolak jika salah satu palsu dan akan diterima jika fakta-fakta membenarkannya, penolakan dan penerimaan hipotesis sangat tergantung pada hasil pebyelidikan terhadap faktafakta yang dikumpulkan." (Sutrisno Hadi, 1992:257).

Berdasarkan kedua pendapat diatas, dapat diketahui bahwa hipotesis adalah merupakan jawaban sementara terhadap permasalahan yang diajukan. Benar atau tidaknya hipotesis yang diajukan tersebut tergantung dari data hasil penelitian dilapangan. Dalam skripsi ini penulis mempunyai hipotesis sebagai berikut :
"Adanya pengaruh yang positif antara pemberian insentif terhadap motivasi kerja pegawai pada Kantor Lembaga Penjaminan Mutu Pendidikan (LPMP) Bandar Lampung".

\section{TINJAUAN PUSTAKA \\ 2.1.Pengertian Insentif}

Sumber daya manusia merupakan salah satu faktor penting disamping sumber daya yang lainnya dalam suatu organisasi baik itu organisasi pemerintah maupun swasta. Lancar tidaknya suatu organisasi sangat ditentukan oleh sikap dan tindakan manusia dalam melaksanakan pekerjaan, sehingga untuk menggerakan pegawai memerlukan suatu perhatian khusus.

Menyadari hal tersebut, pimpinan dari suatu organisasi harus dapat menggerakan secara maksimal dan seefesien mungkin semua potensi kerja pegawai. Untuk menggerakan manusia memerlukan suatu dorongan yang berupa pemberian insentif dalam bentuk material maupun non material. 
Seorang pekerja dengan memperoleh kepuasan dan balas jasa yang tinggi maka semakin tinghi pula semangat kerjanya, sehingga kemauan dan semangat kerja yang tinggi dari pada pegawai teesebut didasarkan atas kesadaran dan loyalitas serta bukan didasarkan atas paksaan dari pimpinan.

Untuk memperjelas pengertian insentif, penulis akan uraikan tentang pengertian insentif.

Menurut Winardi (1999:245), dalam arti luas insentif artinya perangsang atau daya tarik, yaitu:

1. Suatu stimulan ekstra organik yang dikombinasikan dengan suatu faktor intra organik atau lebih, guna menimbulkan aktifitas.

2. Suatu stimulan ekstra organik yang ditujukan untuk mengarahkan kelakuan tertentu atau untuk mempertahankan kelakuan tertentu.

Dari dua macam penjabaran arti insentif tersebut diatas, dilihat dari sasaran oprasional guna menimbulkan aktifitas dan untuk mengarahkan atau mempertahankan kelakuan tertentu.

Sedangkan Robert Dubin (1995:217) berpendapat bahwa insentif adalah perangsang yang menjadi sebab berlangsungnya kegiatan mengarah langsung atau tujuan yang lebih layak/baik dari yang lain.

Pendapat lain diungkapkan oleh Morris S. Viteles (1955:78) yang mengatakan bahwa insentif adalah merupakan keadaan yang membangkitkan kekuatan dinamis manusia, atau persiapan-persiapan dari pada keadaan yang mengantarkan dengan harapan dapat mempengaruhi atau merubah sikap atau tingkah laku manusia.
Dari pengertian-pengertian insentif diatas, dapat disimpulkan bahwa insentif adalah suatu perangsang atau daya tarik yang sengaja diberikan pada pegawai atau karyawan dengan tujuan ikut membangun, memelihara dan memperkuat harapan-harapan karyawan atau pegawai agar dalam diri mereka timbul semangat yang lebih besar untuk berprestasi bagi organisasi.

Kemudian setelah dikemukakan tentang pengertian insentif, maka berikut ini akan dibahas tentang bentuk-bentuk dari insentif.

Menurut Morris S. Viteles (1955:41), ada dua bentuk dari insentif adalah sebagai berikut:

1. Insentif yang bersifat positif Insentif yang bersifat positif dalam arti mau berbuat sesuatu untuk membentuk, untuk melancarkan atau mengembangkan terutama bentuk dan tingkah laku, sebagaimana hadiah-hadiah yang berupa material, pujian merasa berhasil dengan baik dan sebagainya.

2. Insentif yang bersifat negatif Insentif yang bersifat negatif dalam arti tanggapan atau reaksi yang melarang dan menghalanghalangi serta menghambat atau sejenisnya yang lain, sebagaimana misalnya: tegoran, hukuman-hukuman, pemecatan atau penghapusan hak-hak istimewa dan sebagainya.

Jadi jelaslah bahwa bentuk-bentuk insentif ada yang berbentuk positif dan negatif, dimana kedua bentuk insentif tersebut merupakan salah satu dari sekian banyak yang bermanfaat untuk meningkatkan produktivitas karyawan.

\subsection{Tujuan Insentif}

Unsur organisasi yang sangat penting adalah kesediaan dari anggota 
untuk mengembangkan usaha mereka dalam bentuk kerja sama. Suatu kekuatan kerja sama yang luar biasa jika dibandingkan dengan kekuatan sejumlah orang yang lebih banyak tetapi tidak terorganisir.

Salah satu faktor penggerak berupa insentif. Sebagaimana dikemukakan oleh Robert Dubin (1995:213), mengatakan bahwa insentif adalah perangsang yang menjadikan sebab berlangsungnya kegiatan.

Senada dengan itu Morris S. Viteles (1955:76) juga mengatakan bahwa insentif adalah keadaan yang membangkitkan kekuatan dinamis manusia atau persiapan-persiapan dari pada kekuatan dinamis manusia atau persiapan-persiapan dari pada keadaan yang mengantarkan dengan harapan dapat mempengaruhi atau merubah sikap/tingkah laku manusia.

Menurut Malayu SP. Hasibuan, (1997:195), pemberian insentif atau perangsang mempunyai tujuan pokok, yaitu:

1. Bagi pimpinan, untuk dapat semakin meningkatkan kemauan kerja pegawai sehingga semangat dan kegairahan kerja di segala bidang dan tugas berjalan dengan lancar.

2. Bagi pegawai, untuk dapat semakin memacu pegawai ke arah berpola gerak dan bertindak laku yang sesuai dengan kehendak pimpinan dalam rangka usaha mencapai tujuan kerja sama yang telah ditetapkan perusahaan, disamping itu untuk mewujudkan kemudahan dalam pelaksanaan tugas.

Lebih lanjut Malayu SP. Hasibuan mengatakan, secara rinci rumusan tujuan insentif adalah sebagai berikut:
1. Untuk mengubah perilaku pegawai sesuai dengan keinginan pimpinan

2. Untuk meningkatkan kegairahan kerja pegawai

3. Untuk menjaga kestabilan pegawai

4. Untuk meningkatkan tingkat kesejahteraan pegawai

5. Untuk meningkatkan prestasi pegawai

6. Untuk mempertinggi masuk pegawai

7. Untuk meningkatkan rasa tanggung jawab pegawai pada tugas-tugasnya

8. Untuk meningkatkan produktivitas dan efisiensi

9. Untuk memperdalam kecintaan pegawai terhadap perusahaan

10. Untuk memperbesar partisipasi pegawai terhadap perusahaan

Jadi pemberian insentif terhadap para pegawai akan menumbuhkan semangat kerja pegawai. Hal ini mengingat bahwa insentif ini merupakan salah satu yang dapat meningkatkan semangat kerja pegawai khususnya pegawai pada Kantor Lembaga Penjaminan Mutu Pendidikan (LPMP) Bandar Lampung.

\subsection{Pengertian Motivasi Kerja}

Salah satu sumber daya manusia Indonesia yang memiliki peranan dalam kegiatan organisasi pemerintah adalah pegawai dan juga merupakan salah satu kekayaan yang harus dimanfaatkan untuk menjadi aset yang bermanfaat bagi pembangunan. Untuk dapat melaksanakan tugas organisasi dalam hal pemanfaatan pegawai, perlu adanya jalan atau cara yang harus ditempuh demi menghasilkan tujuan dari organisasi, salah satu caranya yaitu dengan memberi motivasi kepada pegawai. Motivasi yang diberikan kepada pegawai dapat berupa penghargaan, gaji, kesejahteraan pegawai, promosi sesuai dengan 
kemampuan biologis dan rohaninya. Oleh sebab itu tindakan yang cermat dan bijaksana harua diambil dalam membekali dan mempersiapkan para pegawai sehingga benar-benar menjadi pegawai yang produktif.

Motif menurut Sudirman (1996:73) diartikan sebagai gaya penggerak yang mendorong seseorang melakukqn aktivitas-aktivitas tertentu untuk mencapai suatu tujuan. Motif yang sudah aktif disebut motivasi.

Adapun yang dimaksud dengan motivasi menurut Drs. Moekijat (1995:180) adalah suatu kebutuhan pada tingkat bawah telah dipenuhi, maka kekenyangan kebutuhan ini (kebutuhan sosial, kebutuhan akan keamanan, kebutuhan psikologis) akan menimbulkan kebutuhan untuk memenuhi kebutuhan yang lebih tinggi.

Sedangkan menurut Prof. DR. Buchari Zainun (1992:42) motivasi itu tampak dalam dua segi yang berbeda. Di satu pihak bila dilihat dari seginya yang aktif/dinamis, motivasi tampak sebagai suatu usaha positif dalam menggerakan, mengerahkan dan mengarahkan daya potensi tenaga kerja agar secara produktif berhasil mencapai dan mewujudkan tujuan yang telah ditentukan sebelumnya dan sebaliknya bila dilihat dari seginya yang pasif/statis, maka motivasi akan tampak sebagai kebutuhan dan juga sekaligus sebagai perangsang untuk dapat menggerakkan, mengerahkan dan mengarahkan potensi serta daya kerja manusia tersebut kearah yang diinginkan.

Menurut Hadari
(1999:351) mengemukakan bahwa
motivasi adalah suatu kondisi yang
mendorong atau menjadi penyebab
seseorang melakukan suatu perbuatan
atau kegiatan yang dilakukan secara
sadar, meskipun tidak tertutup
kemungkinan bahwa dalam keadaan
terpaksa seseorang mungkin saja

melakukan sesuatu kegiatan yang tidak disukainya. Kegiatan yang didorong oleh sesuatu yang tidak disukai berupa kegiatan yang terpaksa dilakukan cenderung berlangsung tidak efektif dan tidak efisien.

Berdasarkan definisi dan pendapat tersebut diatas maka dapat disimpulkan bahwa yang dimaksud dengan bentuk motivasi adalah suatu usaha positif dalam menggerakkan, mengerahkan dan mengarahkan daya potensi tenaga kerja agar secara produktif berhasil mencapai dan mewujudkan tujuan yang telah ditentukan sebelumnya sehingga mampu bekerja dan memiliki peranan yang sangat besar dalam pembangunan.

Peningkatan motivasi bagi para pegawai sangat penting, karena dengan adanya motivasi atau dorongan para pegawai akan lebih semangat dalam bekerja. Melalui usaha peningkatan motivasi pegawai disuatu instansi pemerintah dan salah satunya di Kantor Lembaga Penjaminan Mutu Pendidikan, diharapkan mampu mencapai tujuan yang telah ditentukan dalam suatu instansi pemerintahan.

Dengan adanya suatu program peningkatan motivasi dalam instansi tersebut, tujuan pokoknya adalah dapat meningkatkan kemampuan, keterampilan dan sikap pegawai atau anggota organisasi sehingga lebih efektif dan efisien dalam mencapai sasaran program ataupun tujuan organisasi.

Dengan uraian-uraian mengenai motivasi diatas, penukis dapat menyumpulkan bahwa yqng dimaksud dengan motivasi kerja pegawai adalah keseluruhan daya penggerak atau tenaga pendorong yang menimbulkan adanya keinginan untuk melakukan kegiatan atau aktivitas dalam menjalankan tugas sebagai pegawai yang dilaksanakan secara sistematis, berulang-ulang, kontinyu dan progresif untuk mencapai tujuan. 


\subsection{Faktor-Faktor Mempengaruhi Motivasi Kerja}

Tujuan yang hendak dicapai dalam suatu organisasi, baik pemerintah maupun swasta adalah pelaksanaan kegiatan secara tepat waktu sesuai dengan apa yang telah ditetapkan. Dengan demikian biaya yang telah dikeluarkan oleh organisasi dapat dihemat semaksimal mungkin atau dengan istilah lain pencapaian tujuan tersebut dapat berjalan dengan baik dan efektif.

Pencapaian tujuan dalam suatu organisasi baik swasta maupun pemerintah membutuhkan suatu bentuk motivasi kerja untuk pegawainya. Adapun faktor-faktor yang mempengaruhi motivasi kerja pegawai diantaranya adalah adanya kebutuhan yang harus dipenuhi melalui dari kebutuhan biologis yang dibawa sejak lahir sampai dengan kebutuhan psikologis yang kompleks.

Suatu motif akan menguasai tingkah laku seseorang bila motif yang berada di bawahnya sudah dipenuhi. Tingkah laku manusia mula-mula dikuasai oleh motif yang lebih rendah, yaitu motif fisikologis seperti lapar, haus, seks, dan sebagainya. Setelah motif dasar terpenuhi, motif diatasnya mulai meguasai sampai dengan motif yang paling tinggi, yaitu motif aktualisasi diri.

Menurut Pyke mengemukakan ciri-ciri umum yang dapat dijadikan sumber motivasi pegawai antara lain: prestasi yang telah dicapai, penghargaan yang diraih, tanggung jawab yang dibebankan, promosi yang diharapkan, kemajuan yang dicapai serta pekerjaan yang dapat dilakukan sendiri.

Motivasi yang mempengaruhi kebutuhan yang paking rendah merupakan motivasi yang paling rendah. Sedangkan motivasi untuk memenuhi kebutuhan yang paling tinggi merupakan motivasi yang paling tinggi. Rendah atau tingginya motivasi tidak terlepas dari keadaan ekonomi seseorang.

Individu yang melepaskan diri dari kemelaratan harus memenuhi kebutuhan dasar, tindakan untuk memenuhi kebutuhan fisiologi/fisik lebih menonjol dari pada kebutuhan lainnya.

Berbagai aktivitas dilakukan untuk memenuhi kebutuhan fisisk, disamping itu kebutuhan social mulai dirasakan juga sebagai suatu yang mendesak untuk dipenuhi. Sedangkan bagi individu yang telah memenuhi kebutuhan fisik dan rasa aman sebagian besar aktivitas akan digunakan untuk memenuhi rasa dihargai. Selain faktor ekonomi, keinginan untuk memenuhi kebutuhan dipengaruhi oleh factor sosial cultural, yaitu kebutuhan yang dirasakan lebih penting akan didahulukan.

\section{METODOLOGI PENELITIAN 3.1.Gambaran Umum Obyek Penelitian}

Berdasarkan Ketetapan Peraturan Menteri Pendidikan Nasional Nomor 7 Tahun 2007 tentang organisasi dan tata kerja Lembaga Penjaminan Mutu Pendidikan, Lembaga Penjaminan Mutu Pendidikan (LPMP) adalah unit pelaksana teknis Departemen Pendidikan Nasional. LPMP dipimpin oleh seorang Kepala yang berada dibawah dan bertanggungjawab kepada Direktur Jenderal Peningkatan Mutu Pendidikan dan Tenaga Kependidikan.

Adanya tuntutan masyarakat terhadap peningkatan mutu pendidikan, terjadinya disparitas mutu pendidikan, perlunya standar mutu pendidikan secara nasional, serta adanya jaminan pelaksanaan mutu pendidikan di daerah berdasarkan standar nasional merupakan hal-hal yang melatarbelakangi terbentuknya LPMP. 
Adapun dasar hukum pembentukan LPMP adalah:

1. Undang-Undang Nomor 2 Tahun 1989 tentang Sistem Pendidikan Nasional yang diperbarui dengan Undang-Undang Tahun 2003 tentang Sistem Pendidikan Nasional;

2. Peraturan Pemerintah Nomor 38 Tahun 1990 tentang Tenaga Kependidikan;

3. Keputusan Presiden Nomor 177 Tahun 2000 tentang Susunan Organisasi dan Tugas Departemen sebagaimana telah diubah terakhir dengan Keputusan Presiden Republik Indonesia Nomor 82 Tahun 2001;

4. Keputusan Presiden Nomor 102 Tahun 2001 tentang Kependudukan, Tugas, Fungsi, Kewenangan, Susunan Organisasi dan Tata Kerja Departemen sebagaimana telah diubah dengan Keputusan Presiden Republik Indonesia Nomor 45 Tahun 2002;

5. Keputusan Presiden Nomor 228/M Tahun 2001 mengenai Pembentukan Kabinet Gotong Royong;

6. Keputusan Menteri Pendidikan Nasional Nomor 031/2002 tentang Organisasi dan Tata Kerja Direktorat Jenderal Pendidikan Dasar dan Menengah;

7. Surat Perserujuan Menteri Pendayagunaan Aparatur Negara Nomor 127.1/M.PAN/4/2003 tanggal 30 April 2003 tentang Persetujuan Pendirian Lembaga Penjaminan Mutu Pendidikan;

8. Surat Keputusan Menteri Pendidikan Nasional Nomor 087/0/2003 tanggal 4 Juli 2003 tentang Organisasi dan Tata Kerja Lembaga Penjaminan Mutu Pendidikan.
Sedangkan dasar hukum perubahan Tupoksi LPMP adalah:

1. Undang-Undang Nomor 20 Tahun 2003 tentang sistem Pendidikan Nasional (Lembaga Negara RI Tahun 2003 Nomor 78, Tambahan Lembaran Negara RI Nomor 4301);

2. Peraturan Pemerintah Nomor 19 Tahun 2005 tentang Standar Nasional Pendidikan (Lembaga Negara RI Tahun 2005 Nomor 41, Tambahan Lembaran Negara RI Nomor 4496);

3. Peraturan Presiden RI Nomor 9 Tahun 2005 tentang Kependudukan, Tugas, Fungsi, Susunan Organisasi dan Tata Kerja Kementerian Negara RI sebagaimana telah beberapa kali diubah dengan Peraturan Presiden Nomor 94 Tahun 2006;

4. Keputusan Presiden RI Nomor 10 Tahun 2005 tentang Unit Organisasi dan Tugas Eselon I Kementerian Negara RI sebagaimana telah diubah beberapa kali terakhir dengan Peraturan Presiden Nomor 91 Tahun 2006;

5. Keputusan Presiden RI Nomor 187/M tahun 2004 mengenai Pembentukan Kabinet Indonesia Bersatu, sebagaimana telah beberapa kali diubah terakhir dengan Keputusan Presiden RI Nomor 20/P Tahun 2005;

6. Peraturan Menteri Pendidikan Nasional Nomor 8 Tahun 2005 tentang Organisasi dan Tata Kerja Direktorat Jenderal PMPTK;

7. Surat Persetujuan Menteri Negara Pendayagunaan Aparatur Negara Nomor B/243/M.PAN/I/2007 Tanggal 31 Januari 2007.

Tujuan dari terbentuknya Lembaga Penjaminan Mutu Pendidikan (LPMP) 
adalah terjaminnya pelaksanaan pendidikan sesuai dengan standar, norma, kriteria dan pedoman penyelenggaraan pendidikan nasional. Untuk memcapai tujuan yang hendak dicapai oleh LPMP, ada beberapa sasaran yang telah ditentukan LPMP, yaitu:

1. Menjamin mutu pendidikan agar sesuai dengan standar, norma, kriteria dan pedoman penyelanggaraan pendidikan nasional;

2. Menjamin input pendidikan (calon peserta didik) agar sesuai dengan standar, norma, kriteria dan pedoman penyelenggaraan pendidikan nasional;

3. Menjamin tercapainya proses pembelajaran agar sesuai dengan standar, norma, kriteria dan pedoman penyelenggaraan pendidikan nasional;

4. Menjamin mutu lulusan agar sesuai dengan standar, norma, kriteria dan pedoman penyelenggara pendidikan nasional;

5. Menjamin akan dampak hasil yang telah dicapai oleh tamatan pendidikan agar sesuai dengan standar, norma, kriteria dan pedoman penyelenggaraan pendidikan nasional.

Lembaga Penjaminan Mutu Pendidikan (LPMP) mempunyai tugas pokok melaksanakan penjaminan mutu pendidikan dasar dan pendidikan menengah termasuk taman kanak-kanak (TK), raudatul athfal (RA), atau bentuk lain yang sederajat di provinsi berdasarkan kebijakan Menteri Pendidikan Nasional.

Dalam menjalankan tugas pokoknya, LPMP memiliki visi menjadi lembaga penjaminan mutu pendidikan dasar dan menengah berstandar nasional dan berwawasan global serta misi yaitu:

1. Melakukan penjaminan pelaksanaan pendidikan di sekolah sesuai dengan standar yang telah ditetapkan oleh pusat;

2. Memfasilitasi peningkatan mutu tenaga pendidikan sesuai dengan kebutuhan provinsi;

3. Memfasilitasi peningkatan kinerja lembaga pendidikan dasar dan menengah.

Dalam melaksanakan tugasnya, LPMP menyelenggarakan fungsi:

1. Pemetaan mutu pendidikan dasar dan menengah termasuk TK, RA atau bentuk lain yang sederajat.

2. Pengembangan dan pengelolaan sistem informasi mutu pendidikan dasar dan menengah termasuk TK, RA, atau bentuk lain yang sederajat.

3. Supervisi satuan pendidikan dasar dan menengah termasuk TK, RA, atau bentuk lain yang sederajat dalam pencapaian standar mutu pendidikan nasional.

4. Fasilitas sumber daya pendidikan terhadap satuan pendidikan dasar dan menengah termasuk TK, RA, atau bentuk lain yang sederajat dalam penjaminan mutu pendidikan.

5. Pelaksanaan urusan administrasi LPMP.

\subsection{Metode Penelitian}

\subsubsection{Ruang Lingkup Penelitian}

Penelitian ini penulis laksanakan di Kantor Lembaga Penjaminan Mutu Pendidikan (LPMP) Provinsi Lampung..

\subsubsection{Tipe Penelitian}

Tipe penelitian ini adalah penelitian kualitatif dan penelitian kuantitatif. Penelitian kualitatif yang 
menggambarkan keadaan di lapangan berdasarkan kenyataan yang ada yang ditunjang dengan teori dan literatur yang mendukung, sedangkan penelitian kuantitatif yaitu penelitian berdasarkan angka-angka yang didapatkan dari hasil penyebaran angket atau kuisioner yang kemudia diolah menggunakan uji statistik.

Adapun yang menjadi objek dalam pembahasan penelitian ini adalah pegawai pada kantor Lembaga Penjaminan Mutu Pendidikan (LPMP) Provinsi Lampung.

\subsubsection{Metode Penelitian}

Metode penelitian yang penulis lakukan adalah metode survey atau penelitian lapangan yaitu mengadakan penelitian langsung ke objek penelitian untuk memperoleh data sesuai dengan pembahasan penelitian.

\subsubsection{Metode Analisis}

Metode analisis yang diperginakan dalam pembahasan penelitian ini adalah metode kuantitatif, dikarenakan data yang dikumpulkan merupakan data kuantitatif atau data yang berupa angkaangka yang didapatkan dari hasil penyebaran angket (kuisioner) kepada responden penelitian.

\subsection{Teknik Pengumpulan Data}

Untuk mengumpulkan data, penulis menggunakan teknik sebagai berikut:

1. Penelitian perpustakaan Yaitu mempelajari dan menyelidiki serta mengutip secara langsung literatur yang mendukung dalam penulisan skripsi ini.

2. Penelitian lapangan

Yaitu mengumpulkan data atau informasi dengan cara mengambil langsung pada objek penelitian dengan harapan dapat memperoleh data atau informasi yang empiris. Ini merupakan teknik bantu yang digunakan untuk memperoleh data mengenai obyek penelitian.

3. Interview

Adalah pengumpulan data dengan mengadakan tanya jawab pada pegawai sebagai responden yang dijadikan sampel penelitian, juga terhadap para pegawai yang dianggap mengerti permasalahan yang sedang dihadapi.

4. Kuisioner

Merupakan teknik pokok yang digunakan untuk mengungkap data-data tentang pengaruh pemberian insentif terhadap motivasi kerja pegawai yang sedang diselidiki dengan menggunakan daftar pertanyaan yang harus dijawab oleh responden yang menjadi obyek dalam penelitian ini.

5. Dokumentasi

Merupakan sumber informasi berupa bahan-bahan tertulis pada Kantor Lembaga Penjaminan Mutu Pendidikan (LPMP) Provinsi Lampung.

\subsection{Populasi dan Sampel}

\subsubsection{Populasi}

Sebelum penulis menentukan sampel dalam penelitian ini terlebih dahulu penulis menentukan populasinya karena antara keduanya ada pengaruh yang sangat erat satu sama lain.

Oleh karena itu penulis mengutip pendapat Riduwan (2006) yang menyatakan bahwa populasi adalah totalitas semua nilai yang mungkin dihitung atau pengukuran kuantitatif dari objek yang lengkap dan jelas yang ingin dipelajari sifat-sifatnya.

Berdasarkan pendapat diatas maka penulis dapat menyimpulkan bahwa populasi dalam penelitian ini adalah seluruh pegawai pada Kantor Lembaga Penjaminan Mutu Pendidikan (LPMP) 
Provinsi Lampung yang berjumlah 105 orang.

\subsubsection{Sampel}

Untuk menentukan ukuran atau jumlah sampel pada penelitian ini, digunakan batasan yang menyatakan bahwa sebagai ancer-ancer, maka jika jumlah anggota objek penelitian kurang dari 100 orang, lebih baik dilakukan penelitian populasi, tetapi jika subjeknya lebih dari 100 orang maka dapat diambil sebesar 10-15 persen atau 20-25 persen (Suharsimi Arikunto 2004:103).
Dengan pertimbangan tingkat homogenesis anggota populasi yang ada dimana semuanya beratatus PNS dan bekerja pada satu kantor/lembaga, maka dalam penelitian ini penulis mengambil sampel sebesar 25 persen yaitu sebanyak 26 orang dengan menggunakan teknik pengambilan sampel secara acak proposional bertingkat (Stratifield Propotional Random Sampling) dengan perincian sampel penulis sajikan dalam tabel 1 dibawah ini.

Tabel 1. Jumlah sampel yang menjadi responden penelitian pada Lembaga Penjaminan Mutu Pendidikan (LPMP) Provinsi Lampung, 2008

\begin{tabular}{|c|l|c|c|}
\hline No & \multicolumn{1}{|c|}{ Jabatan/Bagian } & $\begin{array}{c}\text { Jumlah Populasi } \\
\text { (Orang) }\end{array}$ & $\begin{array}{c}\text { Jumlah Sampel } \\
\text { (Orang) }\end{array}$ \\
\hline 1. & Kepala LPMP & 1 & 1 \\
\hline 2. & Sub Bagian Umum & 48 & 11 \\
\hline 3. & Seksi Program dan Sistem Informasi & 20 & 5 \\
\hline 4. & Seksi Pemetaan Mutu Supervisi & 19 & 5 \\
\hline 5. & Seksi Fasilitas Sumber Daya Pendidikan & 17 & $\mathbf{2 6}$ \\
\hline \multicolumn{2}{r}{} & $\mathbf{1 0 5}$ & $\mathbf{2 0}$ \\
\hline
\end{tabular}

Sumber: Lembaga Penjaminan Mutu Pendidikan (LPMP) Provinsi Lampung, 2008

\subsection{Teknik Pengolahan Data}

Pengolahan data yang digunakan dalam penelitian ini adalah:

1. Data Primer

Yaitu data yang dikumpulakan dan diolah sendiri oleh suatu organisasi atau perorangan langsung pada obyek pokoknya. Dalam usaha untuk mengumpulkan data primer penulis mengambil beberapa pegawai sebagai responden dan untuk memperoleh data tersebut dipergunakan metode kuisioner dan interview.

2. Data Sekunder
Yaitu data yang diperoleh dalam bentuk yang sudah jadi, sudah dikumpulkan dan diolah pihak lain, biasanya telah dalam bentuk publikasi. Data sekunder diperlukan yaitu tentang Kantor Lembaga Penjaminan Mutu Pendidikan (LPMP) Provinsi Lampung.

\subsection{Teknik Analisis Data}

Proses analisis merupakan usaha untuk menemukan jawaban atas pertanyaan tentang permasalahan yang dirumuskan dan diperoleh selama penelitian. Adapun metode analisis data yang akan digunakan adalah: 


\subsubsection{Analisis Kuantitatif}

Yaitu metode pengolahan data yang berupa angka-angka yang diperoleh agar lebih berdaya guna sehingga nantinya dapat ditarik suatu kesimpulan. Adapun untuk mengetahui korelasi dari dua variabel yaitu variabel bebas dan variabel terikat, penulis menggunakan rumus product moment dengan formulasi sebagai berikut:

$$
r=\frac{N \sum X Y-\left(\sum X\right)\left(\sum Y\right)}{\sqrt{\left(N \sum X^{2}-\left(\sum X\right)^{2}\right)\left(N \sum Y^{2}-\left(\sum Y\right)^{2}\right)}}
$$

Keterangan:

rxy : Koefisien korelasi

$\sum \mathrm{x}$ : Skor variabel bebas

$\sum \mathrm{y}$ : Skor variabel terikat

$\mathrm{n}$ : Jumlah responden

$\sum \mathrm{x} 2$ : Hasil perkalian kuadrat skor dan variabel bebas

$\sum y 2$ : Hasil perkalian kuadrat skor angket dan variabel terikat.

(Sutrisno Hadi, 1999:19)

Sebelum dimasukkan kedalam rumus, maka hasil angket yang terkumpul dari responden, penulis berikan perubahan dimana ketentuan perubahan adalah sebagai berikut:

1. Setiap alternatif jawaban tang diberikan mempunyai skor:

a. Alternatif jawaban a diberi nilai 3

b. Alternatif jawaban b diberi nilai 2

c. Alternatif jawaban c diberi nilai 1

Dari pengertian diatas penulis akan tabulasikan dalam skor hasil jawaban responden variabel $\mathrm{y}$ dan variabel $\mathrm{x}$ dengan jalan menganalisa dan menjumlah skor variabel $\mathrm{x}$ dan variabel $\mathrm{y}$.

2. Menjumlahkan skor variabel $\mathrm{x}$ dan variabel y

3. Memasukkan nilai skor yang disalurkan ke dalam tabel kerja korelasi dengan menganalisanya menggunakan rumus product moment.

Sedangkan untuk mengetahui keeratan pengaruh dua variabel adalah sebagai berikut:

$$
\begin{aligned}
& -0,800-1,000=\text { Sangat tinggi } \\
& -0,600-0,800=\text { Tinggi } \\
& -0,400-0,600=\text { Sedang } \\
& -0,200-0,400=\text { Rendah } \\
& -0,000-0,200=\text { Sangat rendah } \\
& \text { (Sutrisno Hadi, 1991:275) }
\end{aligned}
$$

Selanjutnya penulis menggunakan rumus koefisien penentu (Kp) untuk mengetahui bagaimana pengaruh pemberian motivasi terhadap kinerja pegawai.

$$
K p=r^{2} \times 100 \%
$$

$$
\begin{aligned}
& \text { Keterangan: } \\
& \mathrm{Kp}=\text { Koefisien penentu } \\
& \mathrm{R} 2=\mathrm{r} \text { hitung }
\end{aligned}
$$

Sedangkan untuk menguji signifikan atau tindakannya penulis menggunakan rumus sebagai berikut:

$$
t=\frac{r \sqrt{n-2}}{\sqrt{1-r^{2}}}
$$

Keterangan:

$\mathrm{t}=$ Penguji koefisien korelasi

$r=$ Koefiseien korelasi

$\mathrm{n}=$ Jumlah responden 


\subsubsection{Analisis Kualitatif}

Adalah suatu analisa dengan menggunakan uraian penjelasan dengan cara membandingkan teori dengan pelaksanaan atau praktek pada Kantor Lembaga Penjaminan Mutu Pendidikan (LPMP) Provinsi Lampung.

\section{ANALISIS DATA \\ 4.1.Analisis Kuantitatif}

Analisis kuantitatif ini penulis gunakan untuk mengetahui pengaruh pemberian i sentif terhadap motivasi kerja pegawai pada Kantor Lembaga Penjaminan Mutu Pendidikan (LPMP) Bandar Lampung, dimana seperti telah dikemukakan pada Bab III untuk menganalisis penulis menggunakan korelasi product moment, yaitu sebagai berikut:

$$
r=\frac{N \sum X Y-\left(\sum X\right)\left(\sum Y\right)}{\sqrt{\left(N \sum X^{2}-\left(\sum X\right)^{2}\right)\left(N \sum Y^{2}-\left(\sum Y\right)^{2}\right)}}
$$

Setelah diketahui korelasi dari perhitungan tersebut diatas, kemudian dipergunakan cara pengujian signifikasi dengan tabel $r$, yang dapat disimpulkan sebagai berikut:

1. Apabila hasil perhitungan $r$ hitung lebih besar dari $\mathrm{r}$ tabel, baik pada taraf signigikan 5\% maupun pada taraf $1 \%$, maka kesimpulannya adalah ada pengaruh yang signifikan antara pemberian insentif terhadap motivasi kerja pegawai pada Kantor Lembaga Penjaminan Mutu Pendidikan (LPMP) Bandar Lampung.

2. Apabila hasil perhitungan $r$ hitung lebih kecil dari $\mathrm{r}$ tabel, baik pada taraf signifikan 5\% maupun taraf signifikan $1 \%$, maka kesimpulannya adalah tidak ada pengaruh yang signifikan antara pemberian insentif terhadap motivasi kerja pegawai pada Kantor Lembaga Penjaminan Mutu Pendidikan (LPMP) Bandar Lampung.

(Sutrisno Hadi, 1991:64)

Berdasarkan data yang diperoleh dari tabel kerja korelasi antara pemberian insentif $(\mathrm{X})$ dan motivasi kerja pegawai (Y), maka diketahui data sebagai berikut:

$$
\begin{aligned}
\mathrm{n} & =26 \\
\sum \mathrm{x} & =268 \\
\sum \mathrm{y} & =274 \\
\sum \mathrm{x} 2 & =2798 \\
\sum \mathrm{y} 2 & =2916 \\
\sum \mathrm{xy} & =2847
\end{aligned}
$$

$$
\begin{aligned}
& r x y \\
& =\frac{26(2847)-(268)(274)}{\sqrt{\left(26(2798)-(268)^{2}\right)\left(26(2798)-(274)^{2}\right)}} \\
& =\frac{74022-73432}{\sqrt{(72748-(71824))(75816-(75076))}} \\
& =\frac{590}{\sqrt{(924)(740)}} \\
& =\frac{590}{\sqrt{683760}} \\
& =\frac{624}{826,8978171} \\
& =0,714
\end{aligned}
$$

Dengan demikian dapat dikatakan bahwa pemberian insentif mempunyai pengaruh atau korelasi sangat tinggi terhadap motivasi pegawai pada Kantor Lembaga Penjaminan Mutu Pendidikan (LPMP) Bandar Lampung. Kemudian untuk mengetahui bagaimana keeratan hubungan variabel $X$ terhadap variabel $Y$, dapat diukur dari tabel daftar interprestasi (lihat bab metodologi penelitian) yaitu 0,714 yang terletak 
diantara 0,600 - 0,800 yang berkategori tinggi, dengan demikian pengaruh pemberian insentif terhadap motivasi kerja pegawai pada Kantor Lembaga Penjaminan Mutu Pendidikan (LPMP) Bandar Lampung ini dinilai tinggi.

Setelah diketahui angka koefisien korelasi pada perhitungan sebelumnya, maka untuk mengetahui kadar prosentasi hubungan pemberian insentif terhadap motivasi kerja pegawai tersebut, penulis mempergunakan rumus koefiaien penentu seperti telah disajikan sebelumnya:

$$
\begin{aligned}
\mathrm{Kp} & =\mathrm{r} 2 \times 100 \% \\
& =(0,714) 2 \times 100 \% \\
& =0,509 \times 100 \% \\
& =50,9 \text { atau } 51 \%
\end{aligned}
$$

Dari perhitungan di atas, dapat disimpulkan bahwa motivasi kerja pegawai pada Kantor Lembaga Penjaminan Mutu Pendidikan (LPMP) Bandar Lampung 51\% dipengaruhi oleh pemberian insentif, sedangkan faktorfaktor lain yang mempengaruhi sebesar $49 \%$.

Dengan kata lain, berarti hipotesis yang diajukan yaitu pemberian insentif berpengaruh positif teehadap motivasi kerja pegawai pada Kantor Lembaga Penjaminan Mutu Pendidikan (LPMP) Bandar Lampung dapat diterima, dalam arti bahwa apabila pemberian insentif baik atau tinggi, maka kinerja pegawai akan meningkat yaitu pada derajat kebebasan 0,05.

\subsection{Analisis Kualitatif}

Pada analisi kualitatif ini penulis juga akan mengemukakan penelitian lapangan mengenai pemberian insentif terhadap tingkat motivasi kerja pegawai. Untuk lebih jelasnya dapat dilihat pada tabel berikut ini:
Tabel 6. Jawaban responden mengenai

\begin{tabular}{|c|c|c|c|}
\hline No & Uraian & Jumlah & Prosentase \\
\hline a. & Ya & 22 & $85 \%$ \\
\hline b. & $\begin{array}{l}\text { Kadang- } \\
\text { kadang }\end{array}$ & 4 & $15 \%$ \\
\hline c. & Tidak & 0 & $0 \%$ \\
\hline & Jumlah & 26 & $100 \%$ \\
\hline
\end{tabular}
apakah dengan diberinya insentif dalam bekerja lebih bersemangat.

Sumber : Data diolah, 2008

Tabel diatas menunjukkan bahwa terdapat 22 (dua puluh dua) pegawai $(85 \%)$ yang menjawab ya akan bersemangat dengab diberinya penghargaan, 4 (empat) pegawai $(15 \%)$ menjawab kadang-kadang dan tidak ada pegawai yang menjawab tidak bersemangat.

Tabel 7. Jawaban responden mengenai apakah menerima insentif sesuai dengan ketentuan yang sudah ditetapkan.

\begin{tabular}{|c|l|c|c|}
\hline No & Uraian & Jumlah & Prosentase \\
\hline a. & Ya & 18 & $69 \%$ \\
\hline b. & $\begin{array}{l}\text { Kadang- } \\
\text { kadang }\end{array}$ & 8 & $31 \%$ \\
\hline c. & Tidak & 0 & $0 \%$ \\
\hline \multicolumn{2}{|c|}{ Jumlah } & $\mathbf{2 6}$ & $\mathbf{1 0 0 \%}$ \\
\hline
\end{tabular}

Sumber : Data diolah, 2008

Tabel diatas menunjukkan bahwa terdapat 18 (delapan belas) pegawai (69\%) yabg menjawab ya, 8 (delapan) pegawai $(31 \%)$ yang menjawab kadangkadang. Alasan 8 (delapan) pegawai menjawab kadang-kadang karena dalam menerima insentif tidak sesuai dengan 
ketentuan, dalam hal ini pegawai yang sering bekerja lembur.

Tabel 8. Jawaban responden mengenai apakah mereka menyadari arti penting dari kesejahteraan yang diberikan kepada pegawai.

\begin{tabular}{|c|l|c|c|}
\hline No & Uraian & Jumlah & Prosentase \\
\hline a. & Ya & 23 & $88 \%$ \\
\hline b. & $\begin{array}{l}\text { Kadang- } \\
\text { kadang }\end{array}$ & 3 & $12 \%$ \\
\hline c. & Tidak & 0 & $0 \%$ \\
\hline \multicolumn{2}{|c|}{ Jumlah } & $\mathbf{2 6}$ & $\mathbf{1 0 0 \%}$ \\
\hline
\end{tabular}

Sumber : Data diolah, 2008

Tabel diatas menunjukkan bahwa terdapat 23 (dua puluh tiga) pegawai $(88 \%)$ yang menjawab ya, 3 (tiga) pegawai (12\%) menjawab kadangkadang dan tidak ada pegawai yang menjawab tidak menyadari arti kesejahteraan yang diberikan.

Dengan demikian dapat disimpulkan bahwa sebagian besar Pegawai Kantor Lembaga Penjaminan Mutu Pendidikan (LPMP) Bandar Lampung menyatakan mereka menyadari arti penting dari kesejahteraan.

Tabel 9. Jawaban responden mengenai apakah promosi yang dilaksanakan masih mengalami hambatan.

\begin{tabular}{|l|l|c|c|}
\hline No & Uraian & Jumlah & Prosentase \\
\hline a. & Ya & 6 & $23 \%$ \\
\hline b. & $\begin{array}{l}\text { Kadang- } \\
\text { kadang }\end{array}$ & 11 & $42 \%$ \\
\hline c. & Tidak & 9 & $35 \%$ \\
\hline \multicolumn{2}{|r|}{ Jumlah } & $\mathbf{2 6}$ & $\mathbf{1 0 0 \%}$ \\
\hline
\end{tabular}

Sumber : Data diolah, 2008
Tabel diatas menunjukkan bahwa pegawai mengalami hambatan dalam pelaksanaan promosi 6 (enam) pegawai $(23 \%)$ yang menjawab ya, 11 (sebelas) pegawai $(42 \%)$ menjawab kadang-kadang dan 9 (sembilan) pegawai $(35 \%)$ menjawab tidak.

Dengan demikian dapat disimpulkan bahwa Pegawai Kantor Lembaga Penjaminan Mutu Pendidikan (LPMP) Bandar Lampung kadangkadang masih mengalami hambatan dalam pelaksanaan promosi jabatan.

Tabel 10. Jawaban responden memgenai apakah pegawai menjalankan dan melaksanakan tugas yang diberikan pimpinan.

\begin{tabular}{|l|l|c|c|}
\hline No & Uraian & Jumlah & Prosentase \\
\hline a. & Ya & 24 & $92 \%$ \\
\hline b. & $\begin{array}{l}\text { Kadang- } \\
\text { kadang }\end{array}$ & 2 & $8 \%$ \\
\hline c. & Tidak & 0 & $0 \%$ \\
\hline \multicolumn{2}{|c|}{ Jumlah } & $\mathbf{2 6}$ & $\mathbf{1 0 0 \%}$ \\
\hline
\end{tabular}

Sumber : Data diolah, 2008

Tabel diatas menunjukkan bahwa pegawai yang menjalankan dan mengerjakan tugas yang diberikan pimpinan adalah 24 (dua puluh empat) pegawai (92\%), yang menjawab kadangkadang 2 (dua) pegawai (8\%) dan tidak seorang pun pegawai yang menjawab tidak.

Dengan demikian dapat disimpulkan bahwa Pegawai Kantor Lembaga Penjaminan Mutu Pe didikan (LPMP) Bandar Lampung selalu menjalankan tugas yang diberikan pimpinan.

Tabel 11. Jawaban responden mengenai apakah pegawai atau 
bawahan pernah memberikan kritik dan saran kepada pimpinan.

\begin{tabular}{|c|l|c|c|}
\hline No & Uraian & Jumlah & Prosentase \\
\hline a. & Ya & 9 & $35 \%$ \\
\hline b. & $\begin{array}{l}\text { Kadang- } \\
\text { kadang }\end{array}$ & 14 & $54 \%$ \\
\hline c. & Tidak & 3 & $12 \%$ \\
\hline \multicolumn{2}{|c|}{ Jumlah } & $\mathbf{2 6}$ & $\mathbf{1 0 0 \%}$ \\
\hline
\end{tabular}

Sumber : Data diolah, 2008

Tabel diatas menunjukkan bahwa pegawai atau bawahan yang mwmberikan kritik dan saran kepada pimpinan 9 (sembilan) pegawai (35\%), yang menjawab kadang-kadang 14 (empat belas) pegawai (54\%) dan yang mejawab tidak sebanyak 3 (tiga) pegawai (12\%).

Dengan demikian dapat disimpulkan bahwa Pegawai Kantor Lembaga Penjaminan Mutu Pendidikan (LPMP) Bandar Lampung kadangkadang memberikan kritik dan saran kepada pimpinan.

Tabel 12. Jawaban responden mengenai apakah dalam hubungan kerjasama di instansi sudah tercapai.

\begin{tabular}{|c|l|c|c|}
\hline No & Uraian & Jumlah & prosentase \\
\hline a. & Ya & 17 & $65 \%$ \\
\hline b. & $\begin{array}{l}\text { Kadang- } \\
\text { kadang }\end{array}$ & 9 & $35 \%$ \\
\hline c. & Tidak & 0 & $0 \%$ \\
\hline \multicolumn{2}{|c|}{ Jumlah } & $\mathbf{2 6}$ & $\mathbf{1 0 0 \%}$ \\
\hline
\end{tabular}

Sumber : Data diolah, 2008

Tabel diatas menunjukkan bahwa yang menjawab hubungan kerja sama di instansi sudah tercapai ada 17 (tujuh belas) pegawai (65\%), yang menjawab kadang-kadang 9 (sembilan) pegawai (35\%) dan tidak ada pegawai yang menjawab tidak.

Dengan demikian maka dapat disimpulkan bahwa Pegawai Kantor Lembaga Penjaminan Mutu Pendidikan (LPMP) Bandar Lampung dalam menjamin hubungan kerja sama telah tercapai.

Tabel 13. Jawaban responden mengenai apakah dalam mengerjakan suatu pekerjaan di kantor tepat pada waktu yang telah ditentukan oleh pimpinan.

\begin{tabular}{|c|l|c|c|}
\hline No & Uraian & Jumlah & Prosentase \\
\hline a. & Ya & 20 & $77 \%$ \\
\hline b. & $\begin{array}{l}\text { Kadang- } \\
\text { kadang }\end{array}$ & 5 & $19 \%$ \\
\hline c. & Tidak & 1 & $4 \%$ \\
\hline \multicolumn{2}{|c|}{ Jumlah } & $\mathbf{2 6}$ & $\mathbf{1 0 0 \%}$ \\
\hline
\end{tabular}

Sumber : Data diolah, 2008

Tabel diatas menunjukkan bahwa dalam mengerjakan suatu pekerjaan di kantor tepat pada waktu yang telah ditetapkan oleh pimpinan adalah 20 (dua puluh) pegawai $(77 \%)$, yang menjawab kadang-kadang ada 5 (lima) pegawai (19\%) dan yang menjawab tidak 1 (satu) pegawai (4\%).

Dengan demikian dapat disimpulkan bahwa Pegwai Kantor Lembaga Penjaminan Mutu Pendidikan (LPMP) Bandar Lampung dalam mengerjakan suatu pekerjaan kantor dapat diselesaikan tepat pada waktu yang telah ditentukan oleh pimpinan. 


\section{KESIMPULAN DAN SARAN 5.1.Kesimpulan}

Berdasarkan uraian-uraian terdahulu yang penulis kemukakan pada Bab IV tentang pembahasan hasil penelitian yang penulis lakukan, maka dalam hal ini penulis memgemukakan kesimpulan sebagai berikut:

1. Pemberian insentif kepada pegawai Kantor Lembaga Penjaminan Mutu Pendidikan (LPMP) Bandar Lampung yang meliputi bonus tahunan, kesejahteraan pegawai, dan promisi mempengaruhi motivasi kerja pegawai, yang meliputi inisiatif dan kreatif, hubungan kerja sama, dan disiplin kerja yang ditandai dengan adanya kelancaran pelaksanaan terhadap semua aktivitas yang dilaksanakan, adanya kerjasama yang baik antara pimpinan dengan pegawai, dan adanya tanggung jawab yang tinggi dari pegawai. Hal ini karena ditunjang dengan adanya pembinaan terhadap sumber daya manusia, adanya pendidikan dan pelatihan yang dilaksanakan, perhatian terhadap kesejahteraan pegawai, sehingga semua aktivitas yang dilaksanakan mencapai sasaran.

2. Untuk motivasi kerja pegawai di Kantor Lembaga Penjaminan Mutu Pendidikan (LPMP) Bandar lampung dilaksanakan dengan baik. Hal ini ditandai dengan adanya tanggung jawab, inisiatif dan kreatif, hubungan kerjasama, disiplin kerja dan bentuk inisiatif berupa bonus tahunan, kesejahteraan pegawai, dan promisi serta penerbitan administrasi, tugas dan disiplin dalam kerja.
3. Berdasarkan analisis dengan menggunakan rumus product moment didapatkan:

a. Hasil rxy product moment $=$ 0,714

Dikonsultasikan dengan tingkat keeratan 2 variabel berada pada tingkat keeratan tinggi, berarti pemberian insentif berpengaruh terhadap motivasi kerja pegawai dengan keeratan tinggi.

b. Untuk mengetahui besar pengaruh pemberian insentif terhadap motivasi kerja pegawai menggunakan koefisien penentu dengan hasil $51 \%$, sedangkan faktor lain $49 \%$ tidak diteliti diantaranya gaya kepemimpinan, tata ruang kantor, suasana (iklim kerja) pegawai.

\subsection{Saran}

Sebagaimana hasil penelitian, menunjukkan bahwa penelitian pemberian insentif mempunyai hubungan yang positif terhadap motivasi pegawai pada Kantor Lembaga Penjaminan Mutu Pendidikan (LPMP) Bandar Lampung, sebagaimana saran yang dapat penulis sampaikan adalah sebagai beeikut:

1. Insentif mempunyai peranan sangat besar dalam suatu organisasi, untuk itu agar di dalam organisasi tersebut dapat berkembang, diperlukan adanya pemberian insentif, adanya bonus tahunan, kesejahteraan pegawai, dan promosi dengan motivasi kerja pegawainya, tanggung jawab, inisiatif dan kreatif, hubungan kerjasama, disiplin kerja yang baik yang dapat dilakukan dengan cara pengembangan pemberian insentif dengan adanya 
pendidikan dan latihan, perhatian terhadap kesejahteraan pegawai dan sebagainya. Dengan demikian seorang pimpinan sangat dibutuhkan peranannya sehingga tujuan yang diinginkan dapat tercapai.

2. Dengan adanya pengaruh pemberian insentif berupa bonus tahunan, kesejahteraan pegawai, promosi yang baik, maka akan menunjang tercapainya motivasi kerja pegawai yang inisiatif dan kreatif, memiliki hubungan kerja sama, serta disiplin kerja. Selain itu pemanfaatan sumber daya manusia harus senantiasa diperhatikan dan diarahkan agar dapat bekerja dengan baik dalam mencapai tujuan yang dikehendaki.

3. Dalam rangka mencapai motivasi kerja pegawai, inisiatif dan kreatif, hubungan kerjasama, disiplin kerja dan pemberian insentifnya berupa bonus tahunan, kesejahteraan pegawai, dan promosi hendaknya pimpinan lebih meningkatkan hubungan kerjasama yang baik, dapat memotivasi pegawai memberikan bimbingan dan pengarahan kepada bawahan sehingga pegawai tersebut mempunyai loyalitas yang tinggi, terhadap pimpinan dan juga mempunyai tanggung jawab yang tinggi terhadap pekerjaan yang dilaksanakan.

\section{DAFTAR PUSTAKA}

Arikunto Suharsimi, 2004, Prosedur Penelitian, Edisi Revisi, PT. Bina Aksara, Jakarta.

Abraham H. Maslow, 1995, Motivasi Dan Kepribadian 2, PT. Pustaka Binaman Pressindo, Jakarta.
Alex S. Nitisemito, 1992, Manajemen Personalia, Ghalia Indonesia, Jakarta.

Barry Cushway, 1996, Human Resource Management (Manajemen SDM), Gramedia, Jakarta.

Dr. Achmad S. Ruky, 2004, Sistern Manajemen Kinerja, Gramedia, Pustaka Utama, Jakarta.

Drs. Moekijat, 1989, Manajemen Kepegawaian, Mandar Maju, Bandung.

Ermaya Suradinata, 2003, Manajemen Sumber Daya Manusia; Suatu Tinjauan Wawasan Masa Depan, Ramadan, Bandung.

Eugene Mckenna \& Nicbeech, 2001, Manajemen Sumber Daya Manusia, Andi, Yogyakarta.

Frank S. Pyke, Better Coaching. 1993. Advance Coachs Manual. Australia: Sports Commision.

Hasibuan Malayu SP., 2005, Manajemen: Dasar, Pengertian dan Masalah, Bumi Aksara, Jakarta.

H. Nainggolan, 1990, Pembinaan Pegawai Negeri Sipil.

Keputusan Menteri Dalam Negeri RI Nomor 29 Tahun 2002 Tentang Pedoman Pengurusan, Pertanggungjawaban, dan Pengawasan Keuangan Serta Tata Cara Penyusunan APBD, Pelaksanaan Tata Usaha Keuangan Daerah dan Penyusunan Perhitungan APBD. Peraturan Pemerintah Nomor 58 Tahun 2005 Tentang Pengelolaan Keuangan Daerah.

Riduwan, 2006, Rumus dan Data Dalam Aplikasi Statistika, Alfabeta, Bandung.

Sugiyono, 2005, Statistika Untuk Penelitian, Alfabeta, Bandung.

Sutrisno Hadi, 2000, Fakta UndangUndang Nomor 22 Tahun 1999 Tentang Otonomi Daerah, Erosco, Bandung. 
1986, Metodologi Penelitian, PT. Bina Aksara, Jakarta.

Wahjo Sumidjo, 1991, Kepemimpinan

Dan Motivasi, Ghalia Indonesia.

Jakarta.
Wahyu dan M. Masduki, 1987, Petunjuk Praktis Pembuatan Skripsi, Jakarta.AA 